\title{
PLASTIC FILM-MULCHING WITH APPROPRIATE SEEDING RATE ENHANCES YIELD AND WATER USE EFFICIENCY OF DRYLAND WINTER WHEAT IN LOESS PLATEAU, CHINA
}

\author{
ZHAO, J. ${ }^{1}-$ KHAN, S. ${ }^{1}-$ ANWAR, $S .{ }^{2}-$ MO, F. ${ }^{1}-$ MIN, S. ${ }^{1 *}-$ YU, S. ${ }^{1}-$ DONG, S. ${ }^{1}-$ REN, A. ${ }^{1}-$ \\ LIN, W. ${ }^{1}-$ YANG, Z. ${ }^{1}-$ HOU, F. ${ }^{1}-$ GAO, Z. ${ }^{*}$ \\ ${ }^{I}$ College of Agriculture, Shanxi Agricultural University, Taigu 030801, Shanxi, PR China \\ ${ }^{2}$ Institute of Molecular Biology and Biotechnology, The University of Lahore, Lahore, Pakistan \\ *Corresponding author \\ e-mail: sunmin@163.com; phone: +86-354-628-7226
}

(Received 23 $3^{\text {rd }}$ Jul 2019; accepted $31^{\text {st }}$ Oct 2019)

\begin{abstract}
The arid and semi-arid regions of Loess Plateau in China are major winter wheat producing areas where water shortage is limiting wheat production. Present study was designed to analyzed the water consumption characteristics of plastic film-mulched wheat under different seeding rates in order to attain a high yield of dryland wheat. Wheat was sown in dryland areas of Shanxi province, China during the 20142016 growing seasons at different seeding rates $\left(60,75,90,105\right.$ and $\left.120 \mathrm{~kg} \mathrm{~h}^{-1}\right)$ under ridged plastic film mulching and flat sowing without mulching. The results showed that the plastic film mulching had increased the total water consumption (7.8-11\%), water use efficiency (7.6\%-11.3\%), number of tillers (8-16\%), and grain yield (15.9-23.6\%). Water use efficiency, water consumption, and yield were highest at $90 \mathrm{~kg} \mathrm{~h}^{-1}$ under film mulching and $105 \mathrm{~kg} \mathrm{~h}^{-1}$ under no mulching. Increasing seeding rate had increased the number of tillers per unit area and leaf area index, while reduced the number of grains per panicle and 1000 grains weight whereas, yield was increased first and then decreased. Therefore, film-mulching with appropriate seeding rate is an effective approach to enhance yield and water use efficiency of dryland wheat.
\end{abstract}

Keywords: dryland wheat, biomass, grain to leaf ratio, planting density, water consumption

\section{Introduction}

Insufficient precipitation during the growth stages of wheat and shortages of irrigation water in dryland wheat (Triticum aestivum L.) producing areas are major constraints to high yield ( $\mathrm{Li}$ et al., 2017). The arid and semi-arid area of the Loess Plateau is typical rainfed and $60 \%$ of the dryland area is under wheat cultivation (Jin et al., 2007). Previous reports indicated that there is a potential to increase wheat yield in this region by sufficient irrigation (Mo et al., 2005; Liu et al., 2007). However, due to the distribution of the area and limited surface and ground water, an increase in irrigation is not possible, therefore, increasing water use efficiency is of great importance (Huang et al., 2003; Mo et al., 2005). The cropping system of the Loess Plateau is mainly a monocropping of winter wheat with a 3-month fallow during the rainy summer season (Deng et al., 2006). Even though the precipitation in this region is enough for the wheat requirement but most of rainfall $(60-70 \%)$ falls during summer season which does not coincide with the growing season of winter wheat (Liu et al., 2007). Therefore, less soil water content severely limits the wheat yield (Sun et al., 2016). Conserving soil moisture at the summer fallow period and adjusting water consumption rate according to the growth stages of plant are the main objectives for sustainable wheat production in Loess Plateau (Zhang et al., 2013; Liang et al., 2019; Xue et al., 2019). Management practices which modulate the plant population density and conserve soil moisture can regulate the seasonal partitioning of water use (Zhang et al., 2013). 
Reduction in grain yield also depends on the physiological stage of the plants under water stress (Destro et al., 2001). Grain yield could be expressed as the product of yield components such as grain weight, number of grains per spike and number of effective tillers. Tillering is important trait which effect yield as less tillers reduce yield by producing less spikes while too high tillering affect yield by reducing water use efficiency, competition for resource utilization and inducing lodging (Hou and Huang, 2009; Wang et al., 2009; Yang et al., 2019). Number of seeds planted and effective number of tillers significantly effect yield. Number of tillers survived until reproductive stage to contribute to yield (Yang et al., 2019). Water stress at the booting and stem elongation stage resulted in tillers mortality by restricting water and nutrient availability. Seeding rate also affect the yield by tillering and water consumption (Ren et al., 2019; Yang et al., 2019). Previous studies indicated that increasing seeding rate to a certain amount could increase the number of spikes and yield of dryland wheat (Ma et al., 2018; Yang et al., 2019). However, higher seeding rate could also increase the water consumption which could induce water shortage at later growth stages (Ren et al., 2019).

Using reasonable cultivation measures to maintain soil moisture and increase yield have always been the main objectives of research in dryland area (Yang and Chai, 2019). Film mulching is one of the effective measures to improving soil water storage and agronomic traits (Wang et al., 2009; Ren et al., 2017). Mulching can effectively conserve the rainwater by reducing evaporation and increase soil water content, promote the transfer of soil moisture from deep to the surface layer by vapor transfer, which can increase efficiency of water utilization during critical growth stage (Hou et al., 2014; Ma et al., 2018). Wang and Shagguan (2015) reported that ridge furrow mulching is the best practice for conserving soil moisture at planting and increasing yield of dryland wheat. It has been studied that the increase in yield by film mulching is based on the higher water consumption of crops, and the water consumption during the whole growth period of crops after mulching is significantly higher than that of open field (Gan et al., 2013; Hou et al., 2013). However, some studies have shown that the film mulching increased water consumption by higher vegetative growth which resulted in less soil moisture at the later stages of growth, leading to reduced yield ( $\mathrm{Li}$ et al., 2000; Zhang et al., 2013). Du et al. (2005) reported that plastic film-mulching increased grain yield but reduced the reproductive allocation and increased the number of sterile tillers due to increased competition between the survived plants.

The water consumption process of crops is affected by many factors and change of soil hydrothermal conditions after film mulching will inevitably affect the growth and development process of crops, which in turn will affect the water consumption characteristics of crops, leading to changes in crop yield and water use efficiency (Huang et al., 2005). In order to reduce the problems caused by water shortage, balancing water consumption by adopting plastic film-mulching and adjusting plating density is one of the important cultivation measures to achieve high yield.

Although plastic film-mulching is being extensively applied in semi-arid and arid regions of North and Northwest China to increase yield, however the underlying mechanisms and impact of plastic film-mulching on crop yields is still under debate. At present only a few researches had focused the water consumption characteristics under plastic film-mulching. Therefore, we designed a two-year study with objectives (i) to analyze the difference in water utilization efficiency and biomass allocation of wheat between ridge-furrow plastic film-mulching and flat planting with no mulching condition, (ii) to optimize the effect of different sowing rates on the water consumption 
and tiller formation, and (iii) to access the contribution of mulching and seeding rate to enhancing yield traits of dryland wheat.

\section{Materials and methods}

\section{Site description}

\section{Subheading}

The field experiment was performed in wheat growing season from 2014-2016 at the Agriculture Station of Shanxi Agricultural University, China. Experimental site is alongside a hill at the dryland area of Loess Plateau, located to the north of Yuncheng Basin, Shanxi province. This winter wheat planting area has semi-arid, monsoon climate with cold and dry winters and warm summers with the typical characteristics of the Loess Plateau. The average annual rainfall is $450-630 \mathrm{~mm}$, average annual temperature is $11-13{ }^{\circ} \mathrm{C}$, annual sunshine is $2,200-2,500 \mathrm{~h}$, and $190-230$ frost-free days. Experimental field has a flat terrain, and soil is clay loam with good permeability and $\mathrm{pH}$ of $20 \mathrm{~cm}$ soil was 7.5-8.0. Nutrient contents of soil are presented in Table 1.

Table 1. Soil properties in experimental location

\begin{tabular}{c|c|c|c|c}
\hline Year & $\begin{array}{c}\text { Organic matter } \\
\left(\mathbf{g ~ k g}^{-\mathbf{1}}\right)\end{array}$ & $\begin{array}{c}\text { Total nitrogen } \\
\left(\mathbf{g ~ k g}^{-\mathbf{1}}\right)\end{array}$ & $\begin{array}{c}\text { Alkaline hydrolysis } \\
\text { nitrogen } \mathbf{( \mathbf { m g ~ k g } ^ { - 1 } )}\end{array}$ & $\begin{array}{c}\text { Available phosphorus } \\
\left(\mathbf{m g ~ k g}^{-\mathbf{1}}\right)\end{array}$ \\
\hline $2014-2015$ & 10.55 & 0.68 & 37.65 & 17.64 \\
$2015-2016$ & 9.27 & 0.86 & 41.31 & 10.25 \\
\hline
\end{tabular}

In this experimental area, wheat is planted once a year without irrigation. Natural precipitation is the main source of water for crop cultivation in this area, and precipitation mainly concentrating in July-September, which is the fallow period of wheat. Precipitation during experimental years and long-term average of 10 years are given in Table 2. Total precipitation in 2014-2015 was $516.7 \mathrm{~mm}$, from which $151.1 \mathrm{~mm}$ was during winter wheat growth period and $365.6 \mathrm{~mm}$ was in the fellow periods. In 2015, precipitation before flowering was more than average in 2015 , but flowering to maturity was $73 \%$ less than the long-term average, and drought was during the grain filling period. In 2015-2016, total precipitation was $386.8 \mathrm{~mm}$, and precipitation during growth and fallow period was $292.1 \mathrm{~mm}$ and $94.7 \mathrm{~mm}$, respectively. Precipitation from sowing to wintering and jointing to maturity was abundant, but the fallow period and wintering to jointing precipitation was about $64 \%$ less than the average precipitation with severe drought during the early growth period.

Table 2. Precipitation at the experimental site in Wenxi $(\mathrm{mm})$

\begin{tabular}{c|c|c|c|c|c|c}
\hline Year & Fallow period & S-W & W-J & J-A & A-M & Total \\
\hline $2005-2016$ mean & $265.0 \pm 107.5$ & $53.2 \pm 35.9$ & $30.2 \pm 13.6$ & $37.8 \pm 15.8$ & $64.4 \pm 29.7$ & $450.5 \pm 96.7$ \\
$2014-2015$ & 365.6 & 21.5 & 50.8 & 61.2 & 17.6 & 516.7 \\
$2015-2016$ & 94.7 & 101.2 & 11.0 & 57.1 & 122.8 & 386.8 \\
\hline
\end{tabular}

Source: Meteorological Observation of Wenxi County, Shanxi Province, China

Fallow period: Jun 21 to Sep 30; S-W (sowing-wintering): Oct 1 to Nov 30; W-J (wintering-jointing): Dec 1 to Apr 10 in the following year; J-A (jointing-anthesis): Apr 11 to May 10; A-M (anthesismaturity): May 11 to Jun 10 


\section{Experimental design and treatments}

The wheat cultivar 'Jinmai92' used in this experiment was obtained from Wenxi Agriculture Bureau. The two factors split-plot design was adopted, the seeding method as the main factor and sowing density as sub-plot factor. The sowing methods were film mulching with ridges and no mulching without ridges. The seeding rates were $60,75,90$, 105 , and $120 \mathrm{~kg} \mathrm{~h}^{-1}\left(\mathrm{D}_{60}, \mathrm{D}_{75}, \mathrm{D}_{90}, \mathrm{D}_{105}, \mathrm{D}_{120}\right)$. All treatments were replicated 3 times. The area of each plot was $135 \mathrm{~m}^{2}(9 \mathrm{~m} \times 15 \mathrm{~m})$.

Winter wheat was sown in October in 2014 and 2015 and harvested in June of the following year. Stubble (about $25 \mathrm{~cm}$ high) was left in field after harvesting wheat. In mid-July, deep ploughing was conducted at the depth of $25-30 \mathrm{~cm}$ and $1500 \mathrm{~kg} \mathrm{~h}^{-1}$ of commercial organic fertilizer (containing $45 \%$ organic matter, $1.2 \%$ available $\mathrm{N}, 1 \%$ available $\mathrm{P}, 0.3 \%$ available $\mathrm{K}$ ) was applied to the soil. In August, rotary tillage was used to crumble large lump and level the fields. Before sowing, $150 \mathrm{~kg} \mathrm{~h}^{-1}$ of nitrogen $(46 \%$ urea), phosphorous $\left(16 \% \mathrm{P}_{2} \mathrm{O}_{5}\right)$ and potassium $\left(52 \% \mathrm{~K}_{2} \mathrm{O}\right)$ were applied to soil and no fertilizer was applied during growth seasons. Ridging, mulching and sowing are completed at one time. The width and height of ridge was $30 \mathrm{~cm}$ and $15 \mathrm{~cm}$ respectively and ridges were covered from top with plastic film (Fig. 1).
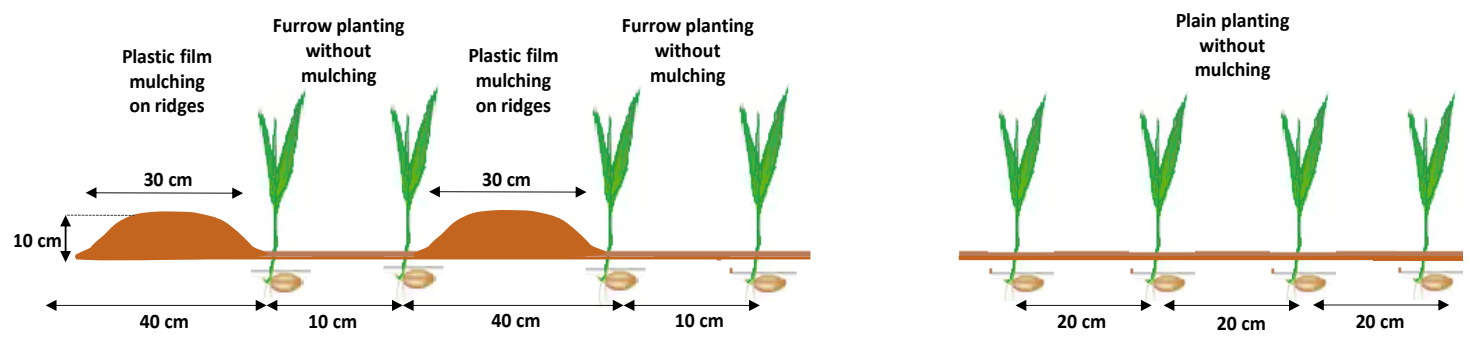

Figure 1. Schematic representation of ridged film-mulching and without mulching

The transparent plastic film with $0.008 \mathrm{~mm}$ thickness and $1.2 \mathrm{~m}$ width was used for mulching. Two rows of wheat were planted on the sides of the ridges at narrow row spacing of $20 \mathrm{~cm}$ and wide row spacing of $40 \mathrm{~cm}$ (Fig. 2). At three-leaf stage, planting density of $150 \times 10^{4}, 187.5 \times 10^{4}, 225 \times 10^{4}, 262.5 \times 10^{4}, 300 \times 10^{4}$ plants $^{-1}$ was attained by thinning. Plastic film was removed 10-15 days after anthesis (mid-May of the next year). In no mulching plots, seeds were sown at $3-5 \mathrm{~cm}$ soil depth at a row spacing of $20 \mathrm{~cm}$. Crop phenology was recorded when half of the plants reached the wintering (GS23), jointing (GS31), anthesis (GS61), and maturity stage (GS92), using the Zadoks scale (Zadoks, 1974). Weeds were controlled by hand.

\section{Plant sampling and analysis}

The plants and soil samples were collected for analysis, according to the phenology of wheat crop (Zadoks, 1974) when 50\% of the wheat plants reached at the corresponding jointing (GS30), anthesis (GS60), and maturity (GS100) stage.

\section{Determination of total stem and tiller and effective tillers rate}

The total number of stems or tillers was investigated at the jointing stage and the number of fertile tillers were counted at late grain filling stage. The number of tillers was calculated from the area of $1 \mathrm{~m}^{2}$ at 3 random points from each plot and average at 
each plot was the number of stem and tillers. The effective tiller rate was calculated as the proportion of main stem and tiller at jointing stage to the number of effective panicles at maturity.

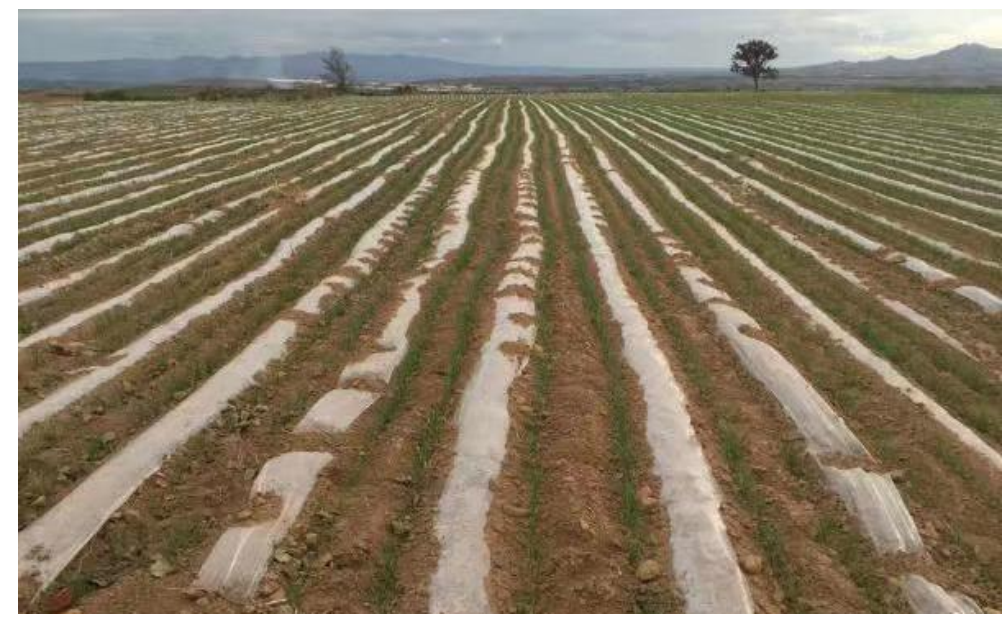

Figure 2. Field preparation at experimental site of Shanxi Agricultural University

\section{Biomass and yield}

At maturity, the number of panicles per unit area, the average number of grains per panicle and weight of 1000 grains were investigated from 50 plants per plot, and plants from $20 \mathrm{~m}^{2}$ area were harvested to calculate economic yield. For determining the aboveground dry biomass, plants samples were kept at $105{ }^{\circ} \mathrm{C}$ for $30 \mathrm{~min}$, and then oven dried at $75^{\circ} \mathrm{C}$ for $12 \mathrm{~h}$ until constant weight.

\section{Leaf area index}

For the determination of leaf area, the length and width of the second leaf and total number of leaves were calculated. Leaf area was measured using the following formula:

\section{Leaf area $=$ length $\times$ width $\times$ number of green leaves $\times 0.85$}

where 0.85 was the adjustment factor. Then leaf area index (LAI) was calculated by dividing the leaf area $\left(\mathrm{cm}^{2}\right)$ by the ground surface area.

\section{Grain to leaf area ratio}

Grain to leaf ratio was calculated according to Feng et al. (1999), using Equations 2 and 3:

$$
\begin{aligned}
& \text { Grain number to leaf area ratio }=\frac{\text { total number of grain per unitarea }}{\text { total leaf area on the same plot at booting stage }}(\text { Eq.2) } \\
& \text { Grain weight to leaf ratio }=\frac{\text { grain weight (mg) per unit area }}{\text { total leaf area on the same plotat booting stage }} \quad \text { (Eq.3) }
\end{aligned}
$$

Total leaf area was taken from the same plot at booting stage $\left(\mathrm{cm}^{2}\right)$. 


\section{Soil sampling and analysis}

\section{Determination of soil moisture}

Soil was drilled from 0-300 $\mathrm{cm}$ depth were with soil drill at sowing, wintering, jointing, flowering and maturity stages. The soil was divided into $20 \mathrm{~cm}$ layers and soil water content and soil water storage were determined.

The soil water storage was calculated by methods as described by He et al. (2009):

$$
\text { SWSi }=\text { Wi } \times \text { Di } \times \text { Hi } \times \frac{10}{100}
$$

where $\mathrm{SWS}_{\mathrm{i}}$ is the soil water storage capacity $(\mathrm{mm})$ of the $\mathrm{i}$-th soil layer; $\mathrm{W}_{\mathrm{i}}$ is the soil water content $(\%)$ of the $\mathrm{i}$-th soil layer; $\mathrm{D}_{\mathrm{i}}$ is the soil bulk density $\left(\mathrm{g} \mathrm{cm}^{-3}\right)$ of the $\mathrm{i}$-th soil layer; $\mathrm{H}_{\mathrm{i}}$ is the thickness of soil layer $(\mathrm{cm})$. The soil water content and soil bulk density were both measured using the oven-drying method (Gardner et al., 1986).

\section{Water consumption}

Water consumption in wheat fields was measured using simplified formula as described by Xue et al. (2019):

$$
E T=P-\Delta S
$$

where $\mathrm{P}$ is the effective precipitation $(\mathrm{mm})$ during that stage and $\Delta \mathrm{S}$ is reduction of soil water storage at each stage and was measured as $\Delta S=S_{1}-S_{2}$, where $S_{1}$ and $S_{2}$ were the soil water content at the beginning and end of the stage, respectively. Whereas, runoff and drainage were considered negligible.

The water consumption intensity $\left(\mathrm{CWR}, \mathrm{mm} \mathrm{d}^{-1}\right)$ was calculated as:

$$
C w R=\frac{E T_{\tilde{i}}}{d}
$$

where ETi is the water consumption $(\mathrm{mm})$ of wheat in each growth stage and $\mathrm{d}$ is the number of days in the growth stage.

Water use efficiency (WUE)

The yield water use efficiency (WUEy) was calculated as:

$$
\text { WUEy } \frac{Y}{E T}
$$

where: $\mathrm{Y}$ is the output, and ET is the total water consumption calculated from Equation 5.

\section{Data processing}

Two-way analysis of variance (ANOVA) was performed to determine the significance of sowing rate and mulching and statistical analysis was carried out using DPS7.05 software and the significant difference among treatments were calculated by least significant difference test (LSD) at the significance level of $p \leq 0.05$. Graphs were 


$$
-1113-
$$

constructed using Microsoft Excel 2010. Pearson correlation coefficients between water consumption and yield related components were assessed at $p \leq 0.05$.

\section{Results}

\section{Soil water content}

Soil water content of 0-300 $\mathrm{cm}$ soil layer was recorded at the wintering, jointing, anthesis and maturity stages under film-mulching and no-mulching (Fig. 3).
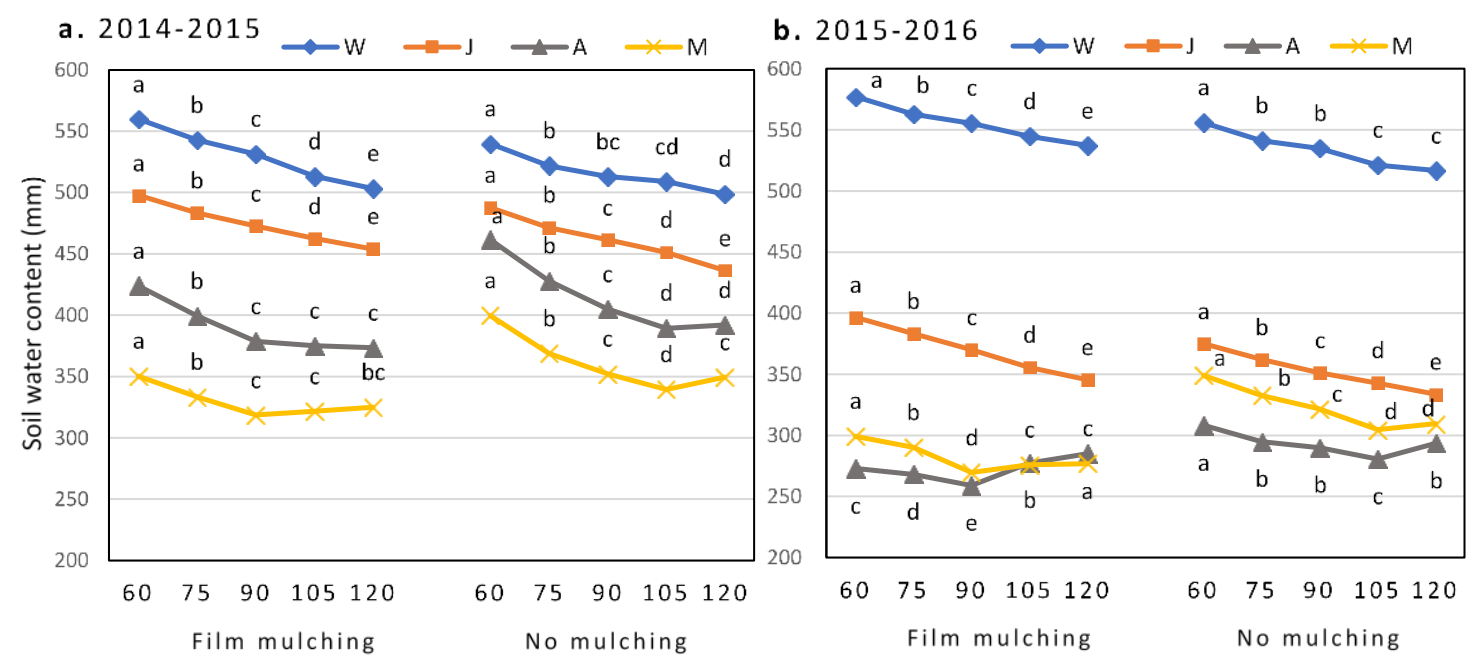

Figure 3. Effects of sowing methods and sowing rates on water content in 0-300 cm soil layer at different growth stages of dryland wheat. $W, J, A$ and $M$ indicate wintering, jointing, anthesis and maturity stages of winter wheat represented by GS23, GS31, GS61 and GS92 respectively, according to Zadoks system. Different letters indicate significant difference among treatments at the significance level of $p \leq 0.05$

At wintering and jointing stages, soil water content of film-mulching treatment was higher than no mulching whereas at the anthesis and maturity stages, water content of no-mulching was higher than the film-mulching. Soil water content was significantly decreased with increasing the seeding rate at wintering and jointing stage. At anthesis and maturity stage, the soil water content was first decreased by increasing the seeding rate and then did not further decreased. Soil water content was also affected by the stages with maximum at wintering, whereas minimum soil water content in 2014-2015 was at maturity and in 2015-2016 was at anthesis stage.

\section{Water consumption at different stages of plastic film mulched wheat}

The total water consumption of plastic film mulched dryland wheat was significantly increased as compared to no mulched during all the growth stages (Fig. 4). By increasing the seeding rate, water consumption was increased first and then decreased, and the highest water consumption was observed at $90 \mathrm{~kg} \mathrm{~h}^{-1}$ under the conditions of film mulching, and at $105 \mathrm{~kg} \mathrm{~h}^{-1}$ under conventional sowing without mulching.

The water consumption of sowing-jointing stage was increased with the increase of sowing quantity (Fig. 4). By increasing the sowing amount, the water consumption at 
jointing-flowering was increased first and then decreased in 2014-2015 with highest at $90 \mathrm{~kg} \mathrm{~h}^{-1}$ under film-mulching and $105 \mathrm{~kg} \mathrm{~h}^{-1}$ under conventional sowing. Whereas in 2015-2016 water consumption at jointing-flowering was reduced with increasing the seeding rate. At flowering to maturity stage, water consumption was decreased in 20142015 whereas increased in 2015-2016 with increasing the seeding rate. It can be seen that the total water consumption of dryland wheat was increased by film mulching, but the difference of precipitation during the growth stages also have a great influence on the water consumption of each stage.
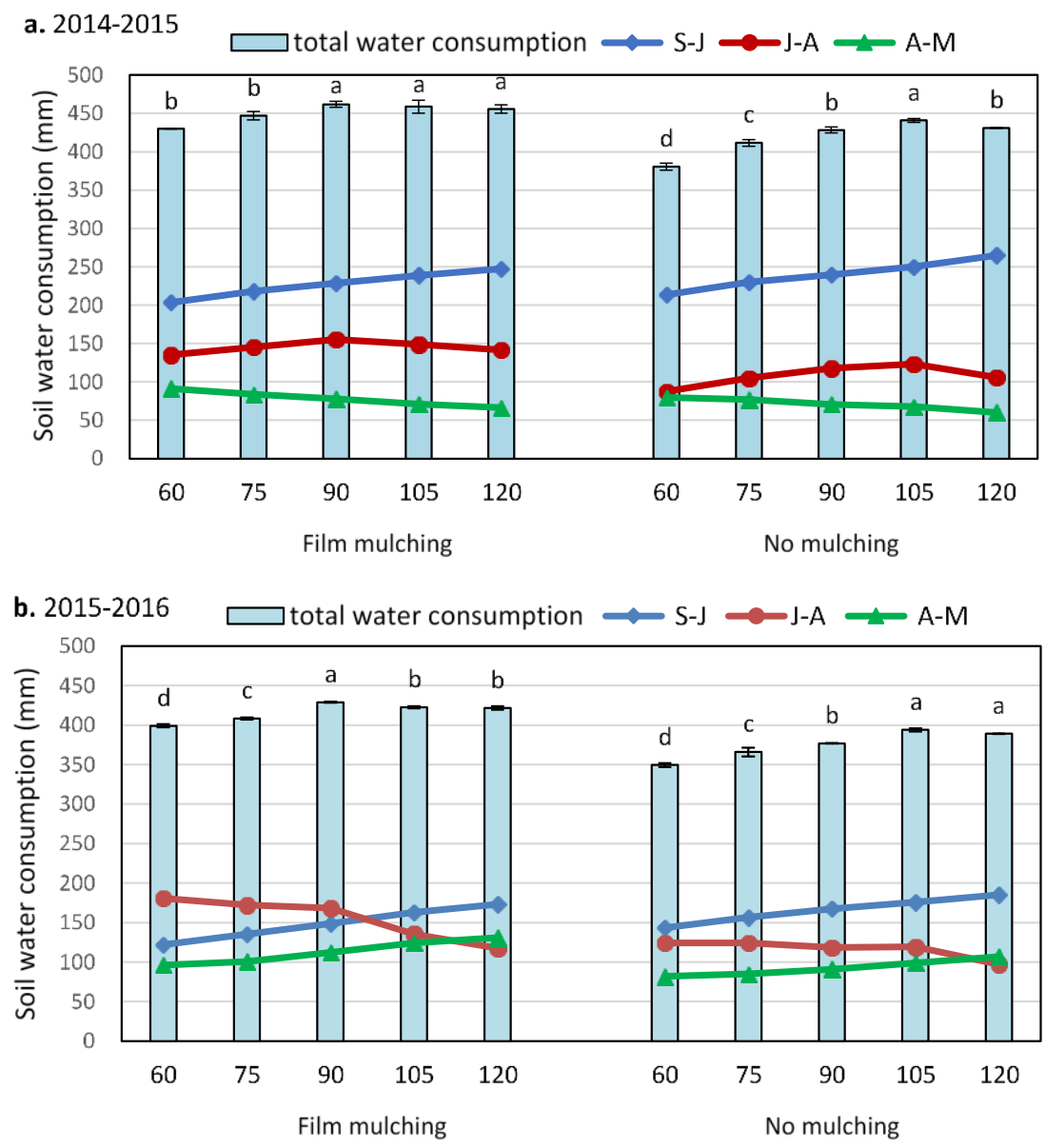

Figure 4. Effects of sowing methods and sowing rates on water consumption of 0-300 cm soil layer at different growth stages of dryland wheat. S-J: Sowing stage to jointing stage, Oct 1 to Apr 10 in the following year; J-A. Jointing stage to anthesis, Apr 11 to May 10; A-M: Anthesis to maturity, May 11 to Jun 10. Different letters indicate significant difference among treatments at the significance level of $p \leq 0.05$

\section{Water consumption rate}

Film mulching reduced the water consumption rate from the sowing-jointing stage compared with no mulching, whereas water consumption rate from jointing to anthesis and anthesis to maturity stage was increased by film mulching (Fig. 5). The water consumption rate of the jointing to anthesis stage was increased first and then decreased with the increasing seeding rate in 2014-2015 and lowest water consumption rate was observed at $90 \mathrm{~kg} \mathrm{~h}^{-1}$ under no-mulching and at $105 \mathrm{~kg} \mathrm{~h}^{-1}$ under film-mulching, 
whereas, in 2015-2016, water consumption rate from jointing to anthesis was decreased with increasing seeding rate. The water consumption rate during the flowering to maturity stage was decreased by increasing the seeding rate in 2014-2015 while in 2015-2016 the water consumption was increased with increasing seeding rate.

\section{Effect of sowing rate and mulching on leaf area and dry biomass}

Film mulching had significantly increased the leaf area index and dry biomass in both years (Table 3).

Table 3. Effect of sowing rate on dry matter formation of wheat covered with plastic film

\begin{tabular}{|c|c|c|c|c|c|c|c|c|c|}
\hline \multirow{3}{*}{\multicolumn{2}{|c|}{ Treatment }} & \multicolumn{4}{|c|}{ 2014-2015 } & \multicolumn{4}{|c|}{ 2015-2016 } \\
\hline & & \multirow{2}{*}{ LAI } & \multicolumn{2}{|c|}{$\begin{array}{c}\text { Grain to leaf area } \\
\text { ratio }\end{array}$} & \multirow{2}{*}{$\begin{array}{c}\text { Dry } \\
\text { biomass } \\
\left(\mathbf{t ~ h a}^{-1}\right)\end{array}$} & \multirow{2}{*}{ LAI } & \multicolumn{2}{|c|}{$\begin{array}{c}\text { Grain to leaf area } \\
\text { ratio }\end{array}$} & \multirow{2}{*}{$\begin{array}{c}\text { Dry } \\
\text { biomass } \\
\left(\mathbf{t ~ h}^{-1}\right)\end{array}$} \\
\hline & & & $\begin{array}{c}\text { GW/leaf } \\
\left(\mathrm{mg} \mathrm{cm}^{-2}\right)\end{array}$ & \begin{tabular}{|c|} 
GN/leaf \\
$\left(\right.$ no. cm$\left.^{-2}\right)$
\end{tabular} & & & \begin{tabular}{|c} 
GW/leaf \\
$\left(\mathrm{mg} \mathrm{cm}^{-2}\right)$
\end{tabular} & \begin{tabular}{|c|} 
GN/leaf \\
$\left(\right.$ no. cm $\left.^{-2}\right)$
\end{tabular} & \\
\hline \multirow{6}{*}{$\begin{array}{l}\text { Film } \\
\text { mulching }\end{array}$} & $\mathrm{D}_{60}$ & $7.53^{\mathrm{e}}$ & $5.6^{\mathrm{b}}$ & $0.133^{\mathrm{bc}}$ & $13.07^{\mathrm{e}}$ & $7.01^{\mathrm{e}}$ & $4.07^{\mathrm{b}}$ & $0.0963^{b}$ & $8.87^{\mathrm{e}}$ \\
\hline & $D_{75}$ & $7.98^{\mathrm{d}}$ & $5.93^{\mathrm{a}}$ & $0.143^{\mathrm{a}}$ & $14.01^{\mathrm{d}}$ & $7.25^{\mathrm{d}}$ & $4.04^{\mathrm{b}}$ & $0.0958^{\mathrm{bc}}$ & $9.25^{\mathrm{d}}$ \\
\hline & $\mathrm{D}_{90}$ & $9.11^{\mathrm{c}}$ & $6.04^{\mathrm{a}}$ & $0.146^{\mathrm{a}}$ & $14.65^{c}$ & $8.04^{\mathrm{c}}$ & $4.46^{\mathrm{a}}$ & $0.1057^{\mathrm{a}}$ & $10.08^{c}$ \\
\hline & $\mathrm{D}_{105}$ & $9.25^{\mathrm{b}}$ & $5.65^{\mathrm{b}}$ & $0.138^{b}$ & $15.44^{\mathrm{b}}$ & $8.12^{\mathrm{b}}$ & $4.14^{\mathrm{ab}}$ & $0.1002^{\mathrm{bc}}$ & $10.36^{\mathrm{b}}$ \\
\hline & $\mathrm{D}_{120}$ & $9.27^{\mathrm{a}}$ & $5.25^{\mathrm{c}}$ & $0.132^{c}$ & $16.26^{\mathrm{a}}$ & $8.58^{\mathrm{a}}$ & $3.52^{\mathrm{c}}$ & $0.0875^{\mathrm{c}}$ & $11.74^{\mathrm{a}}$ \\
\hline & Mean & $8.63^{\mathrm{A}}$ & $5.70^{\mathrm{A}}$ & $0.139^{\mathrm{A}}$ & $14.68^{\mathrm{A}}$ & $7.80^{\mathrm{A}}$ & $4.05^{\mathrm{A}}$ & $0.0971^{\mathrm{A}}$ & $9.86^{\mathrm{A}}$ \\
\hline \multirow{6}{*}{$\begin{array}{l}\text { No } \\
\text { mulching }\end{array}$} & $\mathrm{D}_{60}$ & $6.21^{\mathrm{d}}$ & $5.80^{\mathrm{a}}$ & $0.138^{\mathrm{ab}}$ & $11.53^{\mathrm{e}}$ & $4.87^{\mathrm{e}}$ & $4.81^{\mathrm{a}}$ & $0.1141^{\mathrm{a}}$ & $6.68^{\mathrm{e}}$ \\
\hline & $\mathrm{D}_{75}$ & $7.49^{c}$ & $5.53^{\mathrm{ab}}$ & $0.136^{\mathrm{b}}$ & $12.82^{\mathrm{d}}$ & $6.00^{\mathrm{d}}$ & $4.09^{\mathrm{b}}$ & $0.0986^{\mathrm{b}}$ & $7.87^{\mathrm{d}}$ \\
\hline & $\mathrm{D}_{90}$ & $8.00^{\mathrm{b}}$ & $5.46^{\mathrm{bc}}$ & $0.135^{\mathrm{b}}$ & $13.72^{\mathrm{c}}$ & $6.47^{\mathrm{c}}$ & $3.93^{\mathrm{b}}$ & $0.0955^{\mathrm{b}}$ & $8.52^{\mathrm{c}}$ \\
\hline & $\mathrm{D}_{105}$ & $8.11^{\mathrm{b}}$ & $5.76^{\mathrm{ab}}$ & $0.145^{\mathrm{a}}$ & $14.72^{\mathrm{b}}$ & $8.01^{\mathrm{b}}$ & $3.52^{\mathrm{c}}$ & $0.0860^{c}$ & $9.25^{\mathrm{b}}$ \\
\hline & $\mathrm{D}_{120}$ & $8.49^{\mathrm{a}}$ & $5.20^{c}$ & $0.135^{\mathrm{b}}$ & $15.37^{\mathrm{a}}$ & $8.18^{\mathrm{a}}$ & $3.17^{\mathrm{c}}$ & $0.0788^{c}$ & $9.40^{\mathrm{a}}$ \\
\hline & Mean & $7.66^{\mathrm{B}}$ & $5.55^{\mathrm{B}}$ & $0.138^{\mathrm{A}}$ & $13.63^{\mathrm{B}}$ & $6.71^{\mathrm{B}}$ & $3.90^{\mathrm{B}}$ & $0.0946^{\mathrm{B}}$ & $8.34^{\mathrm{B}}$ \\
\hline \multirow{3}{*}{ ANOVA } & $\mathrm{M}$ & $2349.2^{* * * *}$ & $20.8^{* * *}$ & $0.93^{\text {ns }}$ & $1.92^{* * *}$ & $2430.6^{* * *}$ & $12.5^{* *}$ & $6.2^{*}$ & $36.9^{* * * *}$ \\
\hline & D & $1387.8^{* * * *}$ & $38.7^{* * *}$ & $14.2^{* * *}$ & $2.64^{* * * *}$ & $1596.5^{* * * *}$ & $81.9^{* * * *}$ & $55.6^{* * * *}$ & $67.8^{* * * *}$ \\
\hline & $\mathrm{M} \times \mathrm{D}$ & $56.7^{* * *}$ & $21.3^{* * * *}$ & $20.9^{* * *}$ & $0.03^{* * *}$ & $326.9^{* * *}$ & $36.4^{* * * *}$ & $33.4^{* * * *}$ & $4.06^{* * * *}$ \\
\hline
\end{tabular}

Means followed by different small letters indicate significant difference among treatments within seeding method, and capital letters indicate difference among seeding method at 0.05 level. $\mathrm{D}_{60}, \mathrm{D}_{75}$, $D_{90}, D_{105}$, and $D_{120}$ are $60,75,90,105$ and $120 \mathrm{~kg} \mathrm{seeds}^{-1}$; GW: grain weight; GN: grain numbers per spike

In film mulched plants, the leaf area index was increased by $13-16 \%$, the grain weight to leaf area ratio was increased by $2.7-3.8 \%$, the grain number to leaf area ratio was increased by $0.6-3 \%$, and grain yield was increased by $4.9-7.5 \%$ as compared to no mulching. It can be seen that the film mulching treatment has improved the balance of source reservoir relationship and increased grain yield of wheat during the growth and development of wheat as compared to no mulching.

The leaf area index was gradually increased with the increase in seeding rate and leaf area index at $120 \mathrm{~kg} \mathrm{~h}^{-1}$ was significantly higher than the lower rates. Grain to leaf ratio was first increased and then decreased under film-mulching with maximum grain to leaf area observed at $90 \mathrm{~kg} \mathrm{~h}^{-1}$. The dry biomass was minimum at the lowest seeding rate and was increased by increasing seeding rate reaching maximum at $120 \mathrm{~kg} \mathrm{~h}^{-1}$. Without 
mulching, increasing seeding rate did not significantly enhanced the grain to leaf area ratio. Therefore, the yield could be effectively increased by improving the grain to leaf ratio in the suitable range of leaf area index.
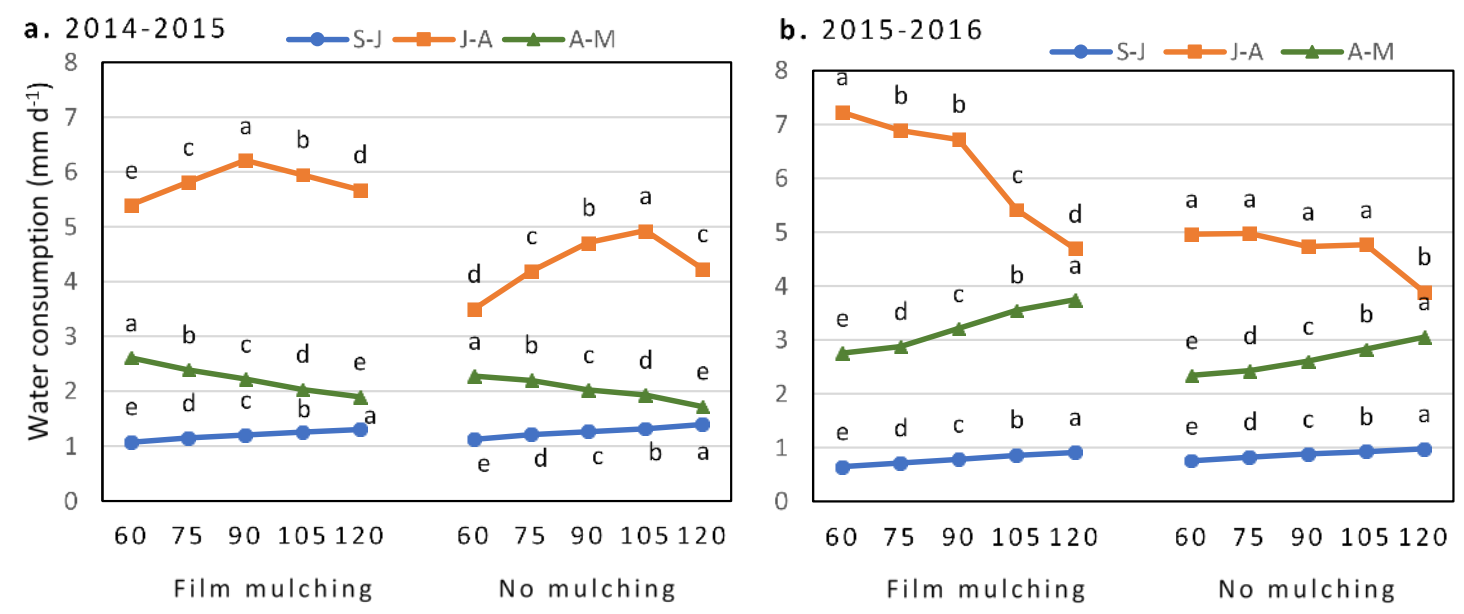

Figure 5. Effects of sowing rate on daily water consumption amount of dryland wheat at different growth stages under different sowing patterns. S-J: Sowing stage to jointing stage, Oct

1 to Apr 10 in the following year; J-A. Jointing stage to anthesis, Apr 11 to May 10; A-M: Anthesis to maturity, May 11 to Jun 10. Different letters indicate significant difference among treatments at the significance level of $p \leq 0.05$

\section{Effect of sowing rate and mulching on tillers formation of wheat}

The mulching has effectively increased the number of tillers at jointing by 3-4\% and the effective number of panicles by $8-16 \%$ as compared to the conventional sowing (Fig. 6).

The number of tillers at the jointing stage was increased by increasing the amount of sowing rate, whereas, the effective number of tillers at maturity was first increased and then decreased at higher sowing rates. The highest number of effective tillers were recorded at seeding rate of $105 \mathrm{~kg} \mathrm{~h}^{-1}$. Under the same sowing rate, the number of effective tillers were increased by $0.83-7.02 \%$ in film mulched as compared with no mulching.

\section{Effect of sowing rate and mulching on yield}

The grain yield and yield related traits were significantly increased by film mulching as compared to no-mulching (Table 4). The number of grains per pod were increased by $4.25-7.04 \%$, the 1000 -grains weight were increased by $1.2-2.0 \%$, the grain yield was increased by $16-24 \%$, and water use efficiency was improved by $8-11 \%$ as compared to no mulching. With the increase of sowing rate, the 1000-grain weight was decreased gradually and lowest grain weight was observed at the highest density $\left(120 \mathrm{~kg} \mathrm{~h}^{-1}\right)$. In film-mulched plants, the number of grains were not increased by increasing the seeding rate whereas in no-mulching treatment, number of grains were firstly increased by increasing seeding rate reaching maximum at $105 \mathrm{~kg} \mathrm{~h}^{-1}$ and then decreased by further increasing seeding rate to $120 \mathrm{~kg} \mathrm{~h}^{-1}$.

The yield and water use efficiency were increased by increasing seed rate with maximum at $90 \mathrm{~kg} \mathrm{~h}^{-1}$ under film mulching and $105 \mathrm{~kg} \mathrm{~h}^{-1}$ without mulching (Table 4). 
However further increasing seeding rate had significantly decreased the yield and water use efficiency. The conventional treatment with $105 \mathrm{~kg} \mathrm{~h}^{-1}$ was the highest, and the yield increased by 5.4-30.4\% compared with other treatments. Mulching has increased yield by 5.4-30.4\%, 5.8-29.5\% in 2014-2015 and 2015-2016 respectively as compared to without mulching. The water use efficiency was improved by $4.7-21.4 \%$ and $3.4-$ $11.8 \%$ by plastic film mulching in 2014-2015 and 2015-2016 respectively as compared to without mulching.
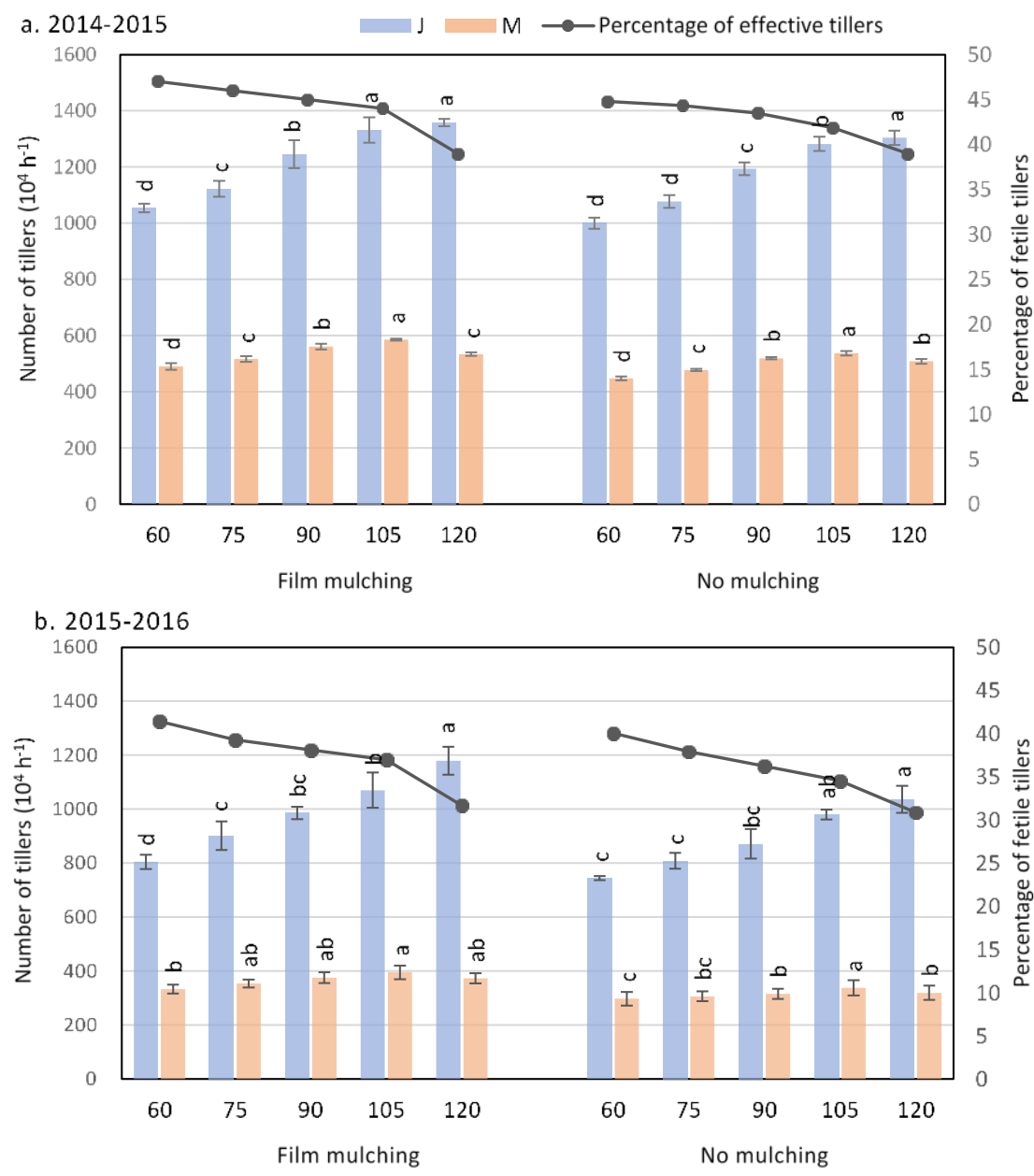

Figure 6. Effects of different sowing rates and mulching on number of tillers at jointing and maturity stage and percentage of effective tillers. Different letters indicate significant difference among treatments at the significance level of $p \leq 0.05$

\section{Correlation analysis of water consumption from soil at different growth stages and yield and yield related components of wheat}

The correlation between water consumption from soil at sowing to jointing, jointing to anthesis and anthesis to maturity stage and yield components were determined (Table 5). It can be seen that the water consumption during different stages have different impact on biomass and yield traits. There was a significant and positive correlation between the leaf area index, grain yield and number of grain and spikes and the amount of water consumed in sowing-jointing and jointing-anthesis stage, and the 


$$
-1118-
$$

influence of water consumption in the stage of sowing to jointing was higher than that in jointing to anthesis. Water consumption in the anthesis-maturity stage was positively correlated with 1000-grain weight, whereas, negatively related with aboveground biomass, LAI, number of spikes, number of grains and grain yield.

Table 4. Effects of different sowing rates on yield formation of wheat covered with plastic film

\begin{tabular}{|c|c|c|c|c|c|c|c|c|c|}
\hline \multirow{2}{*}{\multicolumn{2}{|c|}{ Treatment }} & \multicolumn{4}{|c|}{ 2014-2015 } & \multicolumn{4}{|c|}{ 2015-2016 } \\
\hline & & \multirow{2}{*}{$\begin{array}{c}\begin{array}{c}\text { GN } \\
\left(\text { spike }^{-1}\right)\end{array} \\
33.3^{\mathrm{a}}\end{array}$} & \multirow{2}{*}{$\begin{array}{c}\begin{array}{c}\mathbf{G W} \\
(\mathrm{g})\end{array} \\
42.0^{\mathrm{a}}\end{array}$} & \multirow{2}{*}{$\begin{array}{c}\begin{array}{c}\mathbf{G Y} \\
\left(\mathbf{t} \mathbf{h}^{-\mathbf{1}}\right)\end{array} \\
4.22^{\mathrm{e}}\end{array}$} & \multirow{2}{*}{\begin{tabular}{|c}
$\begin{array}{c}\text { WUEy } \\
\left(\mathbf{k g ~ h}^{-1} \mathbf{~ m m}^{-1}\right.\end{array}$ \\
$9.83^{\mathrm{d}}$
\end{tabular}} & \multirow{2}{*}{$\begin{array}{c}\begin{array}{c}\mathbf{G N} \\
\left(\text { spike }^{-1}\right)\end{array} \\
30.41^{\mathrm{ab}}\end{array}$} & \multirow{2}{*}{$\begin{array}{c}\mathbf{G W} \\
(\mathbf{g})\end{array}$} & \multirow{2}{*}{$\begin{array}{c}\mathbf{G Y} \\
\left(\mathbf{t ~ h}^{-1}\right)\end{array}$} & \multirow{2}{*}{$\begin{array}{c}\begin{array}{c}\text { WUEy } \\
\left(\mathbf{k g ~ h}^{-1}\right. \\
\left.\mathbf{m m}^{-1}\right)\end{array} \\
7.15^{\mathrm{c}}\end{array}$} \\
\hline \multirow{6}{*}{$\begin{array}{l}\text { Film } \\
\text { mulching }\end{array}$} & $\mathrm{D}_{60}$ & & & & & & & & \\
\hline & $\mathrm{D}_{75}$ & $32.5^{\mathrm{ab}}$ & $41.4^{\mathrm{ab}}$ & $4.74^{\mathrm{d}}$ & $10.6^{\mathrm{c}}$ & $28.9^{\mathrm{bc}}$ & $42.2^{\mathrm{ab}}$ & $2.93^{\mathrm{b}}$ & $7.18^{c}$ \\
\hline & $\mathrm{D}_{90}$ & $33.0^{\mathrm{a}}$ & $41.3^{\mathrm{ab}}$ & $5.51^{\mathrm{a}}$ & $11.9^{\mathrm{a}}$ & $32.5^{\mathrm{a}}$ & $42.2^{\mathrm{ab}}$ & $3.59^{\mathrm{a}}$ & $8.37^{\mathrm{a}}$ \\
\hline & $\mathrm{D}_{105}$ & $31.6^{\mathrm{ab}}$ & $40.9^{\mathrm{ab}}$ & $5.23^{\mathrm{b}}$ & $11.4^{\mathrm{b}}$ & $27.8^{\mathrm{cd}}$ & $41.3^{\mathrm{b}}$ & $3.36^{\mathrm{a}}$ & $7.95^{\mathrm{b}}$ \\
\hline & $\mathrm{D}_{120}$ & $30.1^{\mathrm{b}}$ & $39.7^{\mathrm{b}}$ & $4.86^{\mathrm{c}}$ & $10.7^{\mathrm{c}}$ & $26.1^{\mathrm{d}}$ & $40.2^{\mathrm{c}}$ & $3.02^{\mathrm{b}}$ & $7.15^{\mathrm{c}}$ \\
\hline & mean & $32.1^{\mathrm{A}}$ & $41.1^{\mathrm{A}}$ & $4.91^{\mathrm{A}}$ & $10.9^{\mathrm{A}}$ & $30.8^{\mathrm{A}}$ & $41.6^{\mathrm{A}}$ & $3.10^{\mathrm{A}}$ & $7.56^{\mathrm{A}}$ \\
\hline \multirow{6}{*}{ No mulching } & $\mathrm{D}_{60}$ & $30.4^{\mathrm{b}}$ & $41.9^{a}$ & $3.60^{\mathrm{d}}$ & $9.46^{\mathrm{c}}$ & $28.4^{\mathrm{ab}}$ & $42.1^{\mathrm{a}}$ & $2.34^{\mathrm{b}}$ & $6.70^{\mathrm{a}}$ \\
\hline & $\mathrm{D}_{75}$ & $30.0^{\mathrm{b}}$ & $40.7^{\mathrm{b}}$ & $4.14^{\mathrm{c}}$ & $10.1^{\mathrm{b}}$ & $28.6^{\mathrm{ab}}$ & $41.5^{\mathrm{ab}}$ & $2.46^{\mathrm{b}}$ & $6.72^{\mathrm{a}}$ \\
\hline & $\mathrm{D}_{90}$ & $31.2^{\mathrm{ab}}$ & $40.5^{\mathrm{b}}$ & $4.37^{\mathrm{bc}}$ & $10.2^{\mathrm{ab}}$ & $28.1^{\mathrm{ab}}$ & $41.1^{\mathrm{ab}}$ & $2.54^{\mathrm{b}}$ & $6.74^{\mathrm{a}}$ \\
\hline & $\mathrm{D}_{105}$ & $32.7^{\mathrm{a}}$ & $39.6^{\mathrm{c}}$ & $4.67^{\mathrm{a}}$ & $10.6^{\mathrm{a}}$ & $29.1^{\mathrm{a}}$ & $40.9^{\mathrm{ab}}$ & $2.82^{\mathrm{a}}$ & $7.16^{\mathrm{a}}$ \\
\hline & $\mathrm{D}_{120}$ & $29.7^{\mathrm{b}}$ & $38.5^{\mathrm{d}}$ & $4.41^{\mathrm{b}}$ & $10.2^{\mathrm{ab}}$ & $27.9^{\mathrm{b}}$ & $40.2^{\mathrm{b}}$ & $2.59^{\mathrm{ab}}$ & $6.66^{\mathrm{a}}$ \\
\hline & mean & $30.8^{\mathrm{B}}$ & $40.2^{\mathrm{B}}$ & $4.24^{\mathrm{B}}$ & $10.1^{\mathrm{B}}$ & $28.4^{\mathrm{B}}$ & $41.2^{\mathrm{B}}$ & $2.55^{\mathrm{B}}$ & $6.79^{\mathrm{B}}$ \\
\hline \multirow{3}{*}{ ANOVA } & M & $15.7 * * *$ & $15.4^{* * *}$ & $627.1^{* * *}$ & $196.6^{* * * *}$ & $6.02^{*}$ & $7.5^{*}$ & $383.6^{* * * *}$ & $94.4^{* * * *}$ \\
\hline & D & $6.51^{* *}$ & $14.3^{* * *}$ & $201.9^{* * *}$ & $86.6^{* * *}$ & $13.7^{\text {*** }}$ & $9.4^{* * * *}$ & $41.0^{* * * *}$ & $15.2^{* * * *}$ \\
\hline & $M \times D$ & $4.9^{* *}$ & $7.9^{* * *}$ & $20.0^{* * * *}$ & $20.9^{* * * *}$ & $14.6^{* * *}$ & $7.7^{* * * *}$ & $13.8^{* * * *}$ & $9.3^{* * *}$ \\
\hline
\end{tabular}

Means followed by different small letters indicate significant difference among treatments within seeding method, and capital letters indicate difference among seeding method at 0.05 level. $\mathrm{D}_{60}, \mathrm{D}_{75}$, $\mathrm{D}_{90}, \mathrm{D}_{105}$, and $\mathrm{D}_{120}$ are $60,75,90,105$ and $120 \mathrm{~kg}$ seeds $\mathrm{h}^{-1} ; \mathrm{GN}$ : number of grains per spike; GW: 1000 grains weight; GY: grain yield; WUEy: yield water use efficiency

Table 5. Correlation coefficients between water consumption from soil and yield components at different growth stage in dryland wheat

\begin{tabular}{c|c|c|c|c|c|c}
\hline $\begin{array}{c}\text { Water } \\
\text { consumption }\end{array}$ & $\begin{array}{c}\text { Aboveground } \\
\text { biomass }\end{array}$ & LAI & SN & GN & GW & GY \\
\hline S-J & $0.913^{* *}$ & $0.536^{* *}$ & $0.862^{* *}$ & $0.400^{* *}$ & $-0.386^{* *}$ & $0.818^{* *}$ \\
J-A & -0.065 & $0.511^{*}$ & $0.528^{*}$ & $0.323^{*}$ & 0.074 & $0.543^{*}$ \\
A-M & $-0.547^{* *}$ & -0.026 & $-0.603^{* *}$ & $-0.422^{* *}$ & $0.598^{* *}$ & $-0.566^{* *}$ \\
\hline
\end{tabular}

S-J: sowing to jointing; J-A: jointing to anthesis; A-M: anthesis to maturity; S-M: sowing to maturity; LAI: leaf area index; WUEy: yield water use efficiency; SN: number of spikes per panicle; GN: grain number per spike; GW: 1000 grain weight; GY: grain yield ha ${ }^{-1} ; * * *$ and $* * *$ indicate significance at $0.05,0.01$ and 0.001 probability level

\section{Discussion}

Water stress is the main limiting factor for wheat production in Loess Plateau and other arid and semiarid regions (Liu et al., 2007). The growth of winter wheat plants 
depends on the soil water stored by rainfall during summer fallow season (60-70\%) and growing season (30-40\%). The roots of rainfed winter wheat are not able to utilize water from deeper soil layers and ground water in Loess Plateau is below $5 \mathrm{~m}$ (Li et al., 2017). Hence, the limiting precipitation during growth season means that winter wheat must utilize soil water stored from precipitation during fallow season (Xue et al., 2019).

\section{Soil water availability and water use efficiency by ridge plastic mulching}

Mulching is an effective measure to increase soil moisture in arid and semiarid areas. Film mulching can reduce soil surface evaporation and thus improve soil moisture content and promote crop growth and yield (Li et al., 2013). Ridge mulching is one of the main measures to increase agricultural production in arid regions (Zhang et al., 2013). In the present study soil water content of 0-300 $\mathrm{cm}$ depth was higher by plastic film mulching at the wintering and jointing stages. Thus, our study indicated that plastic film mulching effectively relieved the drought stress at early stages of winter wheat growth as similar with Zhao et al. (2016) and Yang et al. (2018). Zhang et al. (2013) reported that ridges mulched with plastic film was better than the straw mulching and other conservation practices in conserving rainfall of summer fallow periods by reducing soil water evaporation.

However, soil water content at anthesis and maturity was higher under no-mulching than the film mulching. This might be because plastic mulching reduces soil surface evaporation at early stages and promote the accumulation of biomass at the vegetative growth with more leaf area which increase transpiration rate ( $\mathrm{Li}$ et al., 2001). The results of present study also indicated that the biomass and leaf area index of mulched wheat was higher than in no mulching (Table 3). Positive effect of plastic film mulching on leaf area index and biomass of wheat was also previously reported ( $\mathrm{Li}$ et al., 2013; Xie et al., 2005).

Therefore, more vegetative growth and high transpiration rate increases utilization of soil water content and manifested by less soil water at late growth stages. Yang et al. (2018) also reported that plastic film mulching conserve soil water in top layers at the early growth stages of spring wheat by decreasing evaporation rate while plants consumed more water from the soil at the middle growth stage under film mulching.

The present study showed that the plastic film-mulching had increased water consumption by $8.4-11 \%$. The plastic film mulch also increased the development and production of biomass by improving the water consumption, similar as previously reported by Niu et al. (2004). Furthermore, increasing water absorption and water consumption by plant also lessen water loss by evaporation (Li et al., 2013).

The water use efficiency of plastic film mulched plants was increased by 7.6-11.3\%, which was consistent to Hou et al. (2013). Water use efficiency was $10.9 \mathrm{~kg} \mathrm{ha}^{-1} \mathrm{~mm}^{-1}$ and $7.6 \mathrm{~kg} \mathrm{ha}^{-1} \mathrm{~mm}^{-1}$ under film mulching and $10 \mathrm{~kg} \mathrm{ha}^{-1} \mathrm{~mm}^{-1}$ and $6.8 \mathrm{~kg} \mathrm{ha}^{-1} \mathrm{~mm}^{-1}$ under no mulching in 2014-2015 and 2015-2016 respectively, as compared with the globally measured average water use efficiency of 6-17 kg ha-1 $\mathrm{mm}^{-1}$ for wheat (Zwart and Bastiaanssen, 2004) and 7-10 kg ha ${ }^{-1} \mathrm{~mm}^{-1}$ for rainfed wheat in Loess Plateau (Huang et al., 2003; Deng et al., 2006). WUE indicates the relationship of production of grain yield and water consumption of the crop (Mo et al., 2005; Jin et al., 2018).

The water for evapotranspiration during the early growth stage comes from stored soil water before sowing and rest from precipitation during growth season (Huang et al., 2003). Soil water conserved at early growth stages is utilized to accumulate biomass and yield formation at the later growth stages and thus improve water use efficiency of 
the crop by changing the pattern of water consumption. Huang et al. (2003) reported that almost $68 \%$ of total water consumed was derived from seasonal precipitation and $32 \%$ derived from the soil water stored from rainfall before planting. The variation in water use efficiency is also attributable to yearly variation in rainfall.

The daily water consumption varied with the growth period of winter wheat and was minimum at sowing to jointing stage and then increased to maximum at jointing to anthesis stage and then decreased at anthesis to maturity. The higher water consumption is at the active growth stage of wheat (Hou et al., 2016). It can be seen that the film mulching reduced the water consumption rate of the initial growth stage (sowing to jointing) and increase the water consumption rate at the late growth stage (jointing to anthesis and anthesis to maturity).

\section{Effect of mulching on yield and relationship between water consumption and yield}

This study showed that both seeding rate and film mulching had significant effects on wheat yield and its components. The number of panicles per unit area was increased by $8-16 \%$, the number of grains per spike were increased by $4.25-7.04 \%$, and the $1000-$ grain weight were increased by $1.2-2.0 \%$, and the yield was increased by $16-24 \%$ in film mulched plants as compared to no mulching and this increase in yield was more prominent in the dry years. Increase in yield of wheat covered by plastic film is mainly to increase the number of spikes per unit area and number of grains per plant. This is because the film mulching can effectively reduce the evaporation of soil moisture, enhance the soil moisture in deep soil layer and improve the growth and development and water use efficiency (Li et al., 2013; Zhang et al., 2013, 2018b).

Zhang et al. (2019) reported a $31 \%$ reduction in soil evaporation and $28 \%$ increase in transpiration rate by plastic film mulching, improving water use efficiency. Similarly, Zhang et al. (2018b) reported $16.1 \%$ increased of grain yield by plastic film mulching and attributed this increase of yield to increase in number of spikes per area and number of grains per spike. However, some contrary studies have shown that mulching resulted in reduced grain yield due to vigorous growth at early stages and lack of soil moisture at the later stages (Li et al., 2001). Zhang et al. (2013) reported that ridge plastic mulching caused increased yield in $20 \%$ cases under different tillage treatments, while $8 \%$ reduction in yield is due to fast depletion of soil water at the early growth stage of wheat due to favorable water conditions under plastic film mulching, which caused water stress at the grain filling stages. Li et al. (2017) reported that grain yield of dryland wheat is mainly limited by soil water content at sowing and increasing soil water at sowing could improve yield.

Previous research indicated that the high yield of the film mulched wheat is based on high water consumption and water utilization efficiency (Hou et al., 2014, 2016; Yang et al., 2015). Plastic film mulching increased the available water content and water consumption during the whole growth period of wheat. This study showed that the number of spikes, grain number and grain yield were significantly positively correlated with water consumption from sowing to jointing and jointing to flowering stage, while negatively correlated with water consumption from flowering to maturity stage (Table 5). The effect on the number of effective panicles was higher than that in jointing-flowering stage. This might be because the number of spikes and grain numbers were determined at early reproductive stage and higher water consumption at jointing to flowering stage resulted in more spikes and grain numbers but with less water content at grain filling stage. In contrast to other yield traits, 1000 grain weight was positively 
related to water consumption from flowering to maturity, showing the importance of available soil water after anthesis on grain filling. Yang et al. (2018) showed that there was a significant positive correlation between yield and water consumption.

Higher soil moisture contents under film mulching also improved the absorption of $\mathrm{N}$ and other nutrients and thus improve the nutrient use efficiency. Studies have shown that the mulching had improved the $\mathrm{N}$ translocation rate before anthesis, $\mathrm{N}$ accumulation to grains after anthesis and nitrogen use efficiency of dryland wheat (Zhang et al., 2016).

The grain yield in 2014-2015 season was higher than in 2015-2016 under both plastic film mulching and no mulching condition. The fluctuation of rainfall in Loess Plateau in different years causes variation in grain yield of dryland wheat (Ren et al., 2019). The total precipitation in 2014-2015 was higher, while in 2015-2016 was less than the longterm average precipitation of the site. Grain yield of wheat is not only influenced by variation in total water content available from seasonal rainfall but also by the pattern of water consumption with growth stages of wheat (O'Leary and Connor, 1997; Ren et al., 2019). Huang et al. (2003) reported a significant relationship between yield of wheat and water consumption during fallow or precipitation during growing season precipitation.

\section{Modulating water consumption and water use efficiency with seeding rate}

Establishing a population structure with high light use efficiency and low water consumption is the fundamental content of high water-saving cultivation of wheat. The water consumption of wheat in dryland is closely related to planting methods and seeding rate. A large number of studies have shown that the amount of seeding rate had a significant impact on wheat growth and water use efficiency (Wang et al., 2017; Ren et al., 2019); therefore, appropriate seeding rate is conducive to increasing soil water storage capacity and water use efficiency in dryland wheat planting areas where soil moisture is the most limiting factor at various growth stages (Ren et al., 2019). Therefore, in the present study wheat was sown at different seeding rates in a ridge and furrow planting method using plastic film mulching whereas, no mulching and plain field was used as a control.

The experimental study showed that the total water consumption during the whole growth period of wheat increased first and then decreased with the increase of the seeding rate and total water consumption was highest at $90 \mathrm{~kg} \mathrm{~h}^{-1}$ under film mulching and $105 \mathrm{~kg} \mathrm{~h}^{-1}$ under no mulching. This indicated that too high or small seeding rate could reduce the water consumption of winter wheat, which is consistent with the results of Wang et al. (2017). However, some studies have shown that water consumption during the whole growth period increases with the increasing seeding rate (Zhang et al., 2018a; Ren et al., 2019). This may be because the water consumption gradually increases from vegetative to reproductive stage. Water consumption at the early stage of wheat from sowing to jointing was increased with increasing the seeding rate due to increase in the amount of evaporation in the wheat field by increasing plant population. Whereas, reduction in field water consumption at jointing to anthesis and anthesis to maturity by increasing seeding rate up to a certain limit might be due to the inhibited growth and premature senescence of high seeded population due to the lack of soil moisture. Therefore, it is necessary to regulate the amount of seeding rate to improve the utilization of water resources and effectively increase crop yield. 
Soil water content was decreased with increasing the seeding rate at wintering, jointing and anthesis stages whereas at maturity stage, soil water content was lowest at $90 \mathrm{~kg} \mathrm{~h}^{-1}$ and $105 \mathrm{~kg} \mathrm{~h}^{-1}$ under film mulching and no mulching respectively. In present study, the pre-anthesis water consumption ratio is higher than the post-anthesis. Ratio of pre-anthesis to post anthesis water consumption varies with the pattern of rainfall, from $3: 1$, when post-anthesis precipitation was less, to $6: 1$ with high post-anthesis rainfall. It has been reported that water used by wheat in a ratio of $2: 1$ before and after anthesis favors yield (Passioura, 1983; Zhang et al., 2013).

\section{Effect of sowing rate on tillering and yield formation}

Population density could influence the ratio of water used and thus yield (Wang, 2010; Zhang et al., 2013). Increasing the amount of seeding rate improves the efficiency of radiation utilization efficiency, and ultimately have a positive effect on formation of grain yield. However, increasing the amount of seeding rate will increase the competition of wheat for resources such as water and nutrients, which will further reduce the grain yield of wheat, accelerate leaf senescence and even reduce the final yield of wheat (Liu et al., 2016). This study showed that the seeding rate had significant effects on wheat yield and its components. Grain yield was first increased with increasing seed rate and reached maximum at $90 \mathrm{~kg} \mathrm{~h}^{-1}$ under mulching and $105 \mathrm{~kg} \mathrm{~h}^{-1}$ under no mulching and then decreased by further increasing seeding rate. Grain yield was maximum at seeding rates where maximum water consumption was observed. Similarly, Ren et al. (2019) also reported that the highest water consumption during the growth stage of winter wheat resulted in highest grain yield in Loess Plateau both in years with low and high rainfall.

Tillering is a key component in determining wheat yield by influencing the photosynthesis rate, plant canopy size and fertile tillers bearing grains. Results from present study indicated that the number of tillers were increased by increasing the seeding rate from 60 to $120 \mathrm{~kg} \mathrm{~h}^{-1}$ at jointing stage whereas at maturity was increased first and then decreased. However, the percentage of fertile tillers were decreased gradually by increasing seeding rate indicating that the number of unproductive tillers were increased at high seeding rate. Generally, from the total tiller initiated, only a proportion of tillers survive to become fertile and others are destined to abort (Xie et al., 2016). The number of aborted tillers varies with the seeding rate and most of previous studies indicated that the effective number of tillers were decreased with increasing the seeding rate (Evers et al., 2006; Kondić et al., 2017). Increasing numbers of unproductive tillers also resulted in high water consumption (Wang et al., 2017). Therefore, seeding rate should be properly optimized because higher number of non-surviving tiller are detrimental for yield due to the loss of dry matter especially in a condition where increase in water use efficiency and yield is most important (Berry et al., 2003).

Number of tillers are determined by the tillers produced and tillers survived. Percentage of effective tillers was highest at the lowest seeding rate but the grain yield was minimum. Because if the seeding rate is too low, the number of tillers per area will be also low due to smaller population resulting in less grain yield per area. This is also indicated by our results as the minimum number of tillers at the jointing and maturity stages were produced at the lowest seeding rate. Increasing seeding rate up to optimum rate at which increasing the number of tillers balance the competition among plants and transfer of photosynthetic products to the grain, and harvest index and the yield per plant are highest. However, if the seeding rate is too high, the grain weight, tillering and 
number of effective tillers are reduced due to the competition for nutrient and light resulting in low yield per plant (Ren et al., 2019). It was obvious from the present results that under film mulching, the maximum yield was attained at relatively low seeding rate $\left(90 \mathrm{~kg} \mathrm{~h}^{-1}\right)$ as compared to without mulching at which the highest yield was attained at $105 \mathrm{~kg} \mathrm{~h}^{-1}$. The high yield at relatively less seeding rate might be related to higher number of effective and survived tillers and increased competition between tillers for resource allocation.

The grain-to-leaf ratio is an effective indicator reflecting the coordination of source and sink relationship and related to density (Serrago et al., 2013). The grain number to leaf area ratio reflects the storage capacity per unit leaf area, while the grain weight to leaf area ratio shows the contribution of unit leaf area to yield, which is used to explain the source quality level and transfer capacity of the source (Wang et al., 2016). Studies have shown that within the range of suitable leaf area index, expanding the total storage capacity and increasing the ratio of grain to leaf is conducive for high yield (Bijanzadeh and Emam, 2010).

This study showed that by increasing the sowing amount, the grain weight-to-leaf ratio and the grain number-to-leaf ratio were increased first and then decreased. The ratio of leaf area to grain weight and number was positively correlated with grain number per spike and 1000 grain weight. Therefore, increasing the ratio of grain to leaf can effectively increase the yield, which is consistent with the results of $\mathrm{Yu}$ et al. (2005). Maximum grain weight to leaf area ratio and grain number to leaf area ratio was attained at $90 \mathrm{~kg} \mathrm{~h}^{-1}$ under film mulching and at $105 \mathrm{~kg} \mathrm{~h}^{-1}$ for plants without mulching.

\section{Conclusion}

The water consumption at different growth stages of dryland wheat field is closely related to wheat yield. The water consumption from sowing to jointing and jointing to anthesis stage was positively related with the spike number, grain number, and grain yield whereas higher water consumption from anthesis to maturity stage was positively related with 1000 grain weight. Plastic film mulching with ridge and furrow planting significantly increased water use efficiency and wheat yield by improving the effective tillers per unit area and number of spikes. Under film mulching, maximum yield was attained at relatively lower seeding rate $\left(90 \mathrm{~kg} \mathrm{~h}^{-1}\right)$ as compared to no mulching at which maximum yield was attained at $105 \mathrm{~kg} \mathrm{~h}^{-1}$. Thus, for the dryland wheat production in Shanxi, seeding rate of $90 \mathrm{~kg} \mathrm{~h}^{-1}$ under film mulching improved the grain to leaf area ratio and relationship between source and sink, increase the number of grains per panicle and 1000-grain weight, increase yield and moisture under the premise of ensuring water use efficiency. Furthermore, in future the effect of different mulching methods on water consumption could be compared.

Acknowledgements. This research work was funded by 'Modern Agriculture Industry Technology System Construction (CARS-03-01-24), The National Key Research and Development Program of China (2018YFD020040105), NSFC (Natural Science Foundation of China) (31771727), Sanjin Scholar Support Special Funds Projects, Research Project Supported by Shanxi Scholarship Council of China (2017-068), Crop Ecology and Dry Cultivation Physiology Key Laboratory of Shanxi Province (201705D111007), Shanxi Provincial Key Research and Development Program (201703D211001), Shanxi Agricultural Valley Construction Research Project (SXNGJSKYZX2017) “1331” Engineering Key Innovation Cultivation Team- Organic Dry Cultivation and Cultivation Physiology Innovation Team and The excellent talents come to Shanxi to reward scientific research projects (SXYBKY201733)'. 


\section{REFERENCES}

[1] Berry, P. M., Spink, J. H., Foulkes, M. J., Wade, A. (2003): Quantifying the contributions and losses of dry matter from non-surviving shoots in four cultivars of winter wheat. Field Crops Research 80: 111-121.

[2] Bijanzadeh, E., Emam, Y. (2010): Effect of source-sink manipulation on yield components and photosynthetic characteristic of wheat cultivars (Triticum aestivum and T. durum L.). - Journal of Applied Sciences 10(7): 564-569.

[3] Deng, X. P., Shan, L., Zhang, H., Turner, N. C. (2006): Improving agricultural water use efficiency in arid and semiarid areas of China. - Agricultural Water Management 80(1-3): 23-40.

[4] Destro, D., Miglioranza, É., Arias, C. A. A., Vendrame, J. M., Almeida, J. C. V. D. (2001): Main stem and tiller contribution to wheat cultivars yield under different irrigation regimes. - Brazilian Archives of Biology and Technology 44(4): 325-330.

[5] Du, Y. J., Li, Z. Z., Li, W. L. (2005): Effect of water control and plastic-film mulch on growth and the range of size inequalities in spring wheat (Triticum aestivum) populations. - New Zealand Journal of Crop and Horticultural Science 33(3): 251-260.

[6] Evers, J. B., Vos, J., Andrieu, B., Struik, P. C. (2006): Cessation of tillering in spring wheat in relation to light interception and red: far-red ratio. - Annals of Botany 97(4): 649-658.

[7] Feng, C. N., Guo, W. S., Wang, F. T., Zhu, X. K., Peng, Y. X. (1999): Mechanism of the population formation with high grain-leaf ratio in wheat. - Scientia Agricultura Sinica 32(6): 47-55.

[8] Gan, Y. T., Siddique, Kadambot, H. M. (2013): Ridge-furrow mulching systems-an innovative technique for boosting crop productivity in semiarid rain-fed environments. Advances in Agronomy 118: 429-476.

[9] Gardner, W. H. (1986): Water Content. - In: Klute, A. (ed.) Methods of Soil Analysis, Part 1-Physical and mineralogical methods. Soil Science Society of America, lnc. Madison, WI, pp. 493-544.

[10] He, J., Kuhn, N. J., Zhang, X. M., Zhang, X. R., Li., H. W. (2009): Effects of 10 years of conservation tillage on soil properties and productivity in the farming-pastoral ecotone of Inner Mongolia, China. - Soil Use and Management 25(2): 201-209.

[11] Hou, H., Huang, G. (2009): Tiller redundancy in winter wheat in irrigated arid areas. Chinese Journal of Eco-Agriculture 17(3): 522-526.

[12] Hou, H. Z., Gao, S., Zhang, X., Wang, D. (2013): Effect of micro ridge-furrow with whole field plastic film mulching and bunching seeding on water consumption characteristics and water use efficiency of winter wheat in semiarid areas of northwest Loess Plateau. - Scientia Agricultura Sinica 49(24): 4701-4713.

[13] Hou, H. Z., Lü, J. F., Guo, T. W., Zhang, G. P., Dong, B., Zhang, X. C. (2014): Effects of whole field soil-plastic mulching on spring wheat water consumption, yield, and soil water balance in semiarid region. - Scientia Agricultura Sinica 47: 4392-4404.

[14] Hou, H. Z., Gao, S. M., Zhang, X. C., Wang, D. G. (2016): Effects of micro ridge-furrow with plastic film mulching and bunching seeding on water consumption characteristics and water use efficiency of winter wheat in semiarid areas of Northwest Loess Plateau. Scientia Agricultura Sinica 49(24): 4701-4713.

[15] Huang, M., Shao, M., Zhang, L., Li, Y. (2003): Water use efficiency and sustainability of different long-term crop rotation systems in the Loess Plateau of China. - Soil and Tillage Research 72(1): 95-104.

[16] Huang, Y., Chen, L., Fu, B., Huang, Z., Gong, J. (2005): The wheat yields and water-use efficiency in the Loess Plateau: straw mulch and irrigation effects. - Agricultural Water Management 72(3): 0-222.

[17] Jin, K., Cornelis, W. M., Schiettecatte, W., Lu, J., Yao, Y., Wu, H. J., Gabriels, D., Neve, S. D., Cai, D. X., Jin, J. Y., Hartmann, R. (2007): Effects of different management 
practices on the soil-water balance and crop yield for improved dryland farming in the Chinese Loess Plateau. - Soil \&Tillage Research 96(1-2): 131-144.

[18] Jin, N., Ren, W., Tao, B., He, L., Ren, Q., Li, S., Yu, Q. (2018): Effects of water stress om water use efficiency of irrigated and rainfed wheat in the Loess Plateau, China. Science of the Total Environment 642: 1-11. DOI: 10.1016/j.scitotenv.2018.06.028.

[19] Kondić, D., Bajić, M., Hajder, Đ., Bosančić, B. (2017): The rate of productive tillers per plant of winter wheat (Triticum aestivum L.) cultivars under different sowing densities. Agro-knowledge Journal 17(4): 345-357.

[20] Li, F. M., Yan, X., Wang, J., Li, S. Q., Wang, T. C. (2001): The mechanism of yield decrease of spring wheat resulted from plastic film mulching. - Scientia Agricultura Sinica 34(3): 330-333.

[21] Li, H., Xun, J. F., Gao, Z. Q., Xue, N. W., Yang, Z. P. (2017): Response of yield increase for dryland winter wheat to tillage practices during summer fallow and sowing method in the Loess Plateau. - Journal of Integrative Agriculture 16: 60345-7.

[22] Li, J., Zhou, D., Wang, P., Lan, L. (2000): The Principals of Winter Wheat Cultivation for High Use Efficiencies of Water and Fertilizers. - Publishing House of China Agricultural University, Beijing, pp. 3-18.

[23] Li, S. X., Wang, Z. H., Li, S. Q., Gao, Y. J., Tian, X. H. (2013): Effect of plastic sheet mulch, wheat straw mulch, and maize growth on water loss by evaporation in dryland areas of China. - Agriculture Water Management 116: 39-49.

[24] Liang, Y. F., Khan, S., Ren, A. X., Lin, W., Anwar, S., Sun, M., Gao, Z. Q. (2019): Subsoiling and sowing time influence soil water content, nitrogen translocation and yield of dryland winter wheat. - Agronomy 9(1): p.37.

[25] Liu, L., Xu, B. C., Li, F. M. (2007): Effects of limited irrigation on yield and water use efficiency of two sequence-replaced winter wheat in Loess Plateau, China. - African Journal of Biotechnology 6(13): 1493-1497.

[26] Liu, T., Wang, Z., Cai, T. (2016): Canopy apparent photosynthetic characteristics and yield of two spike-type wheat cultivars in response to row spacing under high plant density. - PloS One 11(2): e0148582.

[27] Ma, D., Chen, L., Qu, H., Wang, Y., Misselbrook, T., Jiang, R. (2018): Impacts of plastic film mulching on crop yields, soil water, nitrate, and organic carbon in Northwestern China: a meta-analysis. - Agricultural Water Management 202: 166-173.

[28] Ma, S., Yu, Z., Zhang, Y., Zhao, J., Shi, Y., Wang, D. (2014): Effect of field border width for irrigation on water consumption characteristics, yield and water use efficiency of wheat. - Scientia Agricultura Sinica 47(8): 1531D1540.

[29] Ma, S. C., Wang, T. C., Guan, X. K., Zhang, X. (2018): Effect of sowing time and seeding rate on yield components and water use efficiency of winter wheat by regulating the growth redundancy and physiological traits of root and shoot. - Field Crops Research 221: 166-174.

[30] Mo, X., Liu, S., Lin, Z., Xu, Y., Xiang, Y., McVicar, T. R. (2005): Prediction of crop yield, water consumption and water use efficiency with a SVAT-crop growth model using remotely sensed data on the North China Plain. - Ecological Modelling 183(2-3): 301-322.

[31] Niu, J. Y., Gan, Y. T., Huang, G. B. (2004): Dynamics of root growth in spring wheat mulched with plastic film. - Crop Science 44: 1682-1688.

[32] O'Leary, G. J., Connor, D. J. (1997): Stubble retention and tillage in a semi-arid environment: 3. Response of wheat. - Field Crops Research 54: 39-50.

[33] Passioura, J. B. (1983): Roots and drought resistance. - Agriculture Water Management 7: $265-280$.

[34] Ren, A. X., Sun, M., Wang, P. R., Xue, L. Z., Lei, M. M., Xue, J. F., Gao, Z. Q., Yang, Z. P. (2019): Optimization of sowing date and seeding rate for high winter wheat yield based on pre-winter plant development and soil water usage in the Loess Plateau, China. - Journal of Integrative Agriculture 18(1): 33-42. 
[35] Ren, X., Chen, X., Cai, T., Wei, T., Wu, Y., Ali, S., Zhang, P., Jia, Z. (2017): Effects of ridge-furrow system combined with different degradable mulching materials on soil water conservation and crop production in semi-humid areas of China. - Frontiers in Plant Science 8: 1877.

[36] Serrago, R. A., Alzueta, I., Savin, R., Slafer, G. A. (2013): Understanding grain yield responses to source-sink ratios during grain filling in wheat and barley under contrasting environments. - Field Crops Research 150: 42-51.

[37] Sun, S., Wang, Y., Engel, B. A., Wu, P. (2016): Effects of virtual water flow on regional water resources stress: a case study of grain in China. - Science of Total Environment 550: 871-879. DOI: 10.1016/j.scitotenv.2016.01.016.

[38] Wang, B., Zhang, Y., Hao, B., Han, M., Zhao, Z., Wang, Z., Xue, Q. (2017): Late sowing with high seeding rate increases wheat water use efficiency under deficit irrigation. Journal of Soil and Water Conservation 72(6): 629-638.

[39] Wang, L. F., Shangguan, Z. P. (2015): Water-use efficiency of dryland wheat in response to mulching and tillage practices on the Loess Plateau. - Scientific Reports 5: 12225.

[40] Wang, X., Huang, G., Li, Q., Ma, J., Gao, Y., Liu, B. (2010): Characteristics of the evapo-transpiration and its yield performance of rainfed spring wheat and peas fields. Journal of Arid Land Resources and Environment 24: 172-177 (in Chinese).

[41] Wang, Y., Xie, Z., Malhi, S., Vera, C., Zhang, Y., Wang, J. (2009): Effects of rainfall harvesting and mulching technologies on water use efficiency and crop yield in the semiarid Loess Plateau, China. - Agriculture Water Management 96: 374-382. DOI: 10.1016/j.agwat.2008.09.012.

[42] Wang, Y. Q., Xi, W. X., Wang, Z. M., Bin, W. A. N. G., Xu, X. X., Han, M. K., Zhou, S. L., Zhang, Y. H. (2016): Contribution of ear photosynthesis to grain yield under rainfed and irrigation conditions for winter wheat cultivars released in the past 30 years in North China Plain. - Journal of Integrative Agriculture 15(10): 2247-2256.

[43] Xie, Z., Wang, Y., Li, F. (2005): Effect of plastic mulching on soil water use and spring wheat yield in arid region of northwest China. - Agriculture Water Management 75: 7183.

[44] Xie, Q., Mayes, S., Sparkes, D. L. (2016): Optimizing tiller production and survival for grain yield improvement in a bread wheat $\times$ spelt mapping population. - Annals of Botany 117(1): 51-66.

[45] Xue, L., Khan, S., Sun, M., Anwar, S., Ren, A., Gao, Z., Lin, W., Xue, J., Yang, Z., Deng, Y. (2019): Effects of tillage practices on water consumption and grain yield of dryland winter wheat under different precipitation distribution in the loess plateau of China. - Soil and Tillage Research 191: 66-74.

[46] Yang, C. G., Chai, S. X. (2019): Regulatory effects of bundled straw covering on winter wheat yield and soil thermal-moisture utilization in dryland. - Chinese Journal of Applied Ecology 29(10): 3245-3255.

[47] Yang, C. G., Chai, S. X., Chang, L. (2015): Influences of different plastic film mulches on soil water use and yield of winter wheat in semiarid rain-fed region. - Acta Ecologica Sinica 35(8): 2676-2685. DOI: 10.5846/stxb201406051158.

[48] Yang, D., Cai, T., Luo, Y., Wang, Z. (2019): Optimizing plant density and nitrogen application to manipulate tiller growth and increase grain yield and nitrogen-use efficiency in winter wheat. - Peer J 7: e6484.

[49] Yang, J., Mao, X., Wang, K., Yang, W. (2018): The coupled impact of plastic film mulching and deficit irrigation on soil water/heat transfer and water use efficiency of spring wheat in Northwest China. - Agricultural Water Management 201: 232-245.

[50] Yu, J., Liu, Z., Gao, H., Han, Q. (2005): Relationships between the ratios of GNPS/FLA and SGW/FLA with yield in wheat. - Journal of Triticeae Crops 25(1): 61-64.

[51] Zadoks, J. C., Chang, T. T., Konzak, C. F. (1974): A decimal code for the growth stages of cereals. - Weed Research 14: 415-421. 
[52] Zhang, L. L., Sun, S. J., Chen, Z. J., Jiang, H., Zhang, X. D., Chi, D. C. (2018a): Effects of different colored plastic film mulching and planting density on dry matter accumulation and yield of spring maize. - Chinese Journal of Applied Ecology 29(1): 113-124.

[53] Zhang, M., Sun, M., Gao, Z. Q., Zhao, H. M., Li, G., Ren, A. X., Hao, X. Y., Yang, Z. P. (2016): Relationships of water conservation through mulching in fallow period with wheat nitrogen transporation and crop yield in dryland. - Chinese Journal of Applied Ecology 27(1): 117-124.

[54] Zhang, M., Dong, B., Qiao, Y., Yang, H., Wang, Y., Liu, M. (2018b): Effects of sub-soil plastic film mulch on soil water and salt content and water utilization by winter wheat under different soil salinities. - Field Crops Research 225: 130-140.

[55] Zhang, M., Baodi, D., Yunzhou, Q., Hong, Y., Yakai, W., Mengyu, L. (2019): Effects of subsoil plastic film mulch on yield and water use of rainfed winter wheat. - Crop and Pasture Science 69(12): 1197-1207.

[56] Zhang, S., Sadras, V., Chen, X., Zhang, F. (2013): Water use efficiency of dryland wheat in the Loess Plateau in response to soil and crop management. - Field Crop Research 151: 9-18.

[57] Zhao, Y. G., Li, Y. Y., Wang, J., Pang, H. C., Li, Y. (2016): Buried straw layer plus plastic mulching reduces soil salinity and increases sunflower yield in saline soils. - Soil and Tillage Research 155: 363-370.

[58] Zwart, S. J., Bastiaanssen, W. G. M. (2004): Review of measured crop water productivity values for irrigated wheat, rice, cotton and maize. - Agricultural Water Management 69: $115-133$. 